\section{Abbas Fig Cultivar}

\author{
Muhammet A. Gündeşli \\ The Eastern Mediterranean Transitional Zone Agriculture Research \\ Institute, Adana Yolu zeri 5, Km Onikişubat, Kahramanmaras, Turkey
}

Additional index words. breeding, cultivar release, Ficus carica, fig morphology, fig pomology, fruit quality

Fig (Ficus carica L., Moraceae) is among the oldest cultivated fruit trees in the world, and its most important growing center is known to be the Mediterranean region. Recently, fig fruit have attracted much attention because of scientifically confirmed medicinal and nutritional values, including an excellent source of minerals, vitamins and dietary fiber, sugars, organic acids, and phenolic substances, the consumption of which has been proved to have a positive impact on human health. Therefore, fig represents an important component of the Mediterranean diet, and is associated with longevity (Caliskan and Polat, 2012; Ercisli et al., 2012). The Food and Agricultural Organization of the United Nations estimates that 301,062 ha of figs are harvested - more than $1,000,000$ metric tons per year (Food and Agriculture Organization of the United Nations, 2018). In Turkey, locally adapted fig cultivars, landraces, and their wild forms can be found all over the country with a high level of phenotypic diversity, including various color, size, shape, and flavor. In previous years, many important breeding studies on edible fig germplasm have been conducted (Aksoy et al., 2003; Caliskan and Polat, 2012). However, the desired level has not yet been achieved in terms of edible figs and export potential in Turkey. There are also many other local cultivars of great climatic and economic importance (Caliskan and Polat, 2012). Kahramanmaras Province is located in the eastern Mediterranean region where fresh figs are cultivated. The Eastern Mediterranean Transitional Zone Agriculture Research Institute in Kahramanmaras province initiated a fig breeding program in 2016. 'Abbas' was released as a new fig cultivar in Turkey on 25 Oct. 2019. This new cultivar, which has a fruit weight of 70 to $100 \mathrm{~g}$, high yield, and excellent aroma traits, has been widely planted in Kahramanmaras, Turkey. The objective of this study was to identify a high-quality fig cultivar as an alternative to 'Black Bursa' and to help fig growers recognize the new cultivar Abbas as a potential candidate.

Received for publication 20 Apr. 2020. Accepted for publication 27 Apr. 2020.

Published online 5 June 2020.

M.A.G. is the corresponding author. E-mail: muhammetali.gundesli@tarimorman.gov.tr.

This is an open access article distributed under the CC BY-NC-ND license (https://creativecommons. org/licenses/by-nc-nd/4.0/).

\section{Origin}

'Abbas' was selected among a diverse range of genotypes in the Kahramanmaras Province of Turkey in 2017 through 2019. The city of Kahramanmaras is located at a latitude of $37^{\circ} 43^{\prime} \mathrm{N}$, a longitude of $37^{\circ} 8^{\prime} \mathrm{E}$, and an elevation of $900 \mathrm{~m}$ above sea level. It has a continental climate, with the highest average temperature in August $\left(35.9^{\circ} \mathrm{C}\right.$ ), and the lowest average temperature in January $\left(1.2{ }^{\circ} \mathrm{C}\right)$. In our project, called the "Fig Selection Project," the 'Abbas' fig variety was obtained from 8-year-old trees (Fig. 1) where the climate of the region is a typical Mediterranean climate. Pomological characteristics were determined for mature summer crop fruit. From each fig cultivar and type, 30 fruit were selected randomly from the fig trees. Harvested fruit were moved immediately to the Instrumental Analysis Laboratory at Department of Horticulture using cold chain and were then stored at $4{ }^{\circ} \mathrm{C}$. There were three replicates from each cultivar, consisting of 10 fruit. The characterization of plant material was performed using the most important characteristics of fig descriptors of the International Plant Genetic Resources Institute and International Centre for Advanced Mediterranean Agronomic Studies (2003).

\section{Description and Performance}

The aim of our research was to provide data on the new fig cultivar Abbas. Here we report important tree habits and fruit traits according to the fig descriptors of the International Plant Genetic Resources Institute
Fig. 1. 'Abbas' fruit (left) and trees (right). and International Centre for Advanced Mediterranean Agronomic Studies (2003). Our study was certified by the Republic of Turkey, Ministry of Agriculture and Forestry, Variety Registration and Seed Certification Center (2019) (date of request, 30 Oct. 2017; certification no., 2942480).

Biological characteristics. The biological characteristics of fig tree are summarized. According to this, it has been identified as date of bud burst (3-18 Mar.), the beginning of fruit maturation very early ( $<20 \mathrm{July})$, full maturity early (20-31 Aug.), harvest period very long (60 d), onset of caprification early $(<10$ June), and length of the caprification period medium (7-15 d).

Tree and leaf characteristics. According to our findings, terminal bud burst was on 3 Mar. 2017 at the earliest, and on 18 Mar. 2019 at the latest. Plant growth habits included a spreading cultivar (Fig. 1) with trees 7 to $8 \mathrm{~m}$ high and 8 to $9 \mathrm{~m}$ wide, showing vigorous growth and high rooting ability, with a drooping shoot as aging progresses. There were no tubers on trees. The tendency to form root exiles was low. Annual shoot length varied between 21 and $35 \mathrm{~cm}$, and shoot width was less than $10 \mathrm{~mm}$. In terms of 'Abbas' leaf characteristics, the number of leaves per shoot ranged from four to eight, and the predominant leaf type had three lobes.

Fruit characteristics. Fruit characteristics are very important for fresh consumption of figs (Aksoy et al., 2003). Parthenocarpic fruit was not detected. The second product fruits are essentially important and must be fertilized. The fruit are very good-looking and very sweet with a pleasant fragrance. Fruit size is round and flattened in the middle. Fruit yield is good, with more than $50 \mathrm{~kg} /$ tree. The first ripening begins at the beginning of July, reaches peak in mid August, and is completed at the end of September. Harvest time is 40 to $60 \mathrm{~d}$. In our study, fruit weight ranged from 70 to $100 \mathrm{~g}$, and fruit width was more than $60 \mathrm{~mm}$. Fruit flesh is large and plump, and the fruit cavity is either absent or very small in some fruit. It has a short length, and the skin is peeled easily and beautifully. The crust structure is durable, the flesh has a tight texture, and road resistance is good. A large
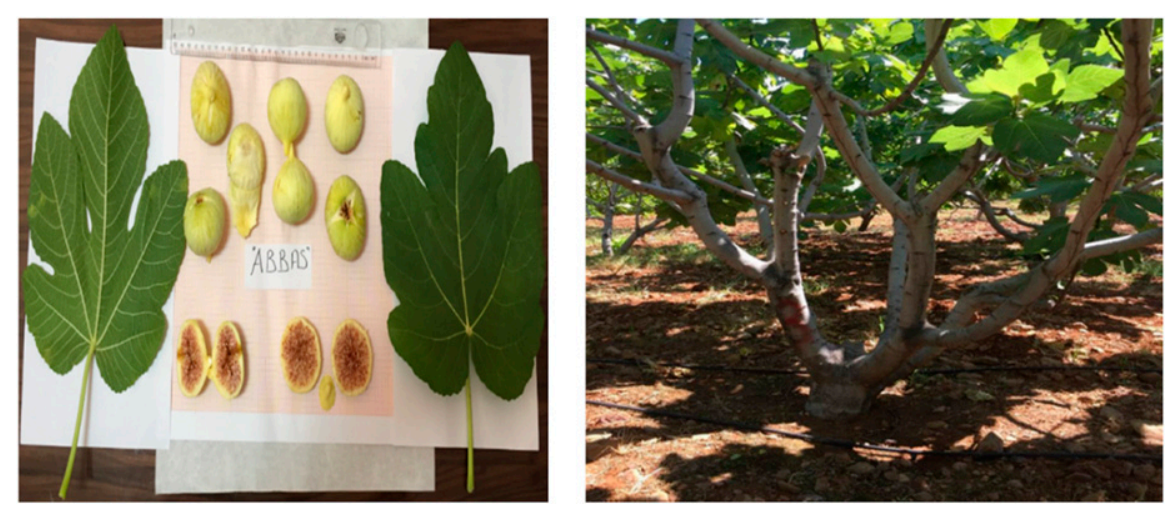
ostiole on the fig is an undesirable characteristic because pests and pathogens enter the fruit. Ostiole width has been reported to be 0.6 to $9.1 \mathrm{~mm}$ (Aksoy et al., 2003), and 1.0 to $9.4 \mathrm{~mm}$ (Polat and Ozkaya, 2005). In our results, ostiole width was less than these results, at 1 to $3 \mathrm{~mm}$. In our study, the total soluble solids content was $16.1 \%$ to $25.0 \%$, which was in agreement with the reports of other studies (Caliskan and Polat, 2012; Soliman et al., 2018). The sugar-to-acid ratio is one of the most important factors in fruit taste (Caliskan and Polat, 2012).

\section{Culture}

'Abbas' is a common fig that is very productive and performs well in cultivation trials and home gardens. This selection has previously been named and propagated unofficially as 'Abbas' in local markets. The cultivar produces larger fruit than the currently proposed cultivars, with good fruit quality, and is consumed extensively by consumers, especially in terms of fruit color, aroma, and size. 'Abbas' offers some unique marketing features for Kahramanmaras Province and many provinces in the southeastern Anatolia region.

\section{Availability}

The Abbas fig cultivar was obtained in the "Fig Selection Project" in Kahramanmaras Province by the Eastern Mediterranean Transitional Zone Agriculture Research Institute. Propagating materials are available at the Eastern Mediterranean Transitional Zone Agriculture Research Institute.

\section{Literature Cited}

Aksoy, U., H.Z. Can, A. Misirli, S. Kara, G. Seferoglu, and N. Sahin. 2003. Fig (Ficus carica L.) selection study for fresh market in western Turkey. Acta Hort. 605:197-203.

Caliskan, O. and A.A. Polat. 2012. Morphological diversity among fig (Ficus carica L.) accessions sampled from the eastern Mediterranean region of Turkey. Turk. J. Agr. For. 36:179-193.

Ercisli, S., M. Tosun, H. Karlidag, A. Dzubur, S. Hadziabulic, and Y. Aliman. 2012. Color and antioxidant characteristics of some fresh fig
(Ficus carica L.) genotypes from northeastern Turkey. Plant Foods Hum. Nutr. 67(3):271-276. Food and Agriculture Organization of the United Nations. 2018. FAOSTAT. 18 Mar. 2018. $<$ http://www.fao.org/faostat/en/\#data/QC>.

International Plant Genetic Resources Institute and International Centre for Advanced Mediterranean Agronomic Studies. 2003. Descriptors for figs. International Plant Genetic Resources Institute (IPGRI), Rome, Italy, and the International Centre for Advanced Mediterranean Agronomic Studies (CIHEAM), Paris, France. $<$ http://agris.fao.org/agris-search/search.do? recordID $=$ QJ2005000011 $>$.

Polat, A.A. and M. Ozkaya. 2005. Selection studies on fig in the Mediterranean Region of Turkey. Pak. J. Bot. 37(3):567-574.

Republic of Turkey, Ministry of Agriculture and Forestry, Variety Registration and Seed Certification Center. 2019. Meyve ve Asma Çeşit Listesi (Fruit Vine). 24 Oct. 2019. <https://www. tarimorman.gov.tr/BUGEM/TTSM/Sayfalar/ Detay.aspx ? SayfaId $=87>$.

Soliman, S.S., A.I. Alebidi, R.S. Al-Obeed, and A.M. Al-Saif. 2018. Effect of potassium fertilizer on fruit quality and mineral composition of fig (Ficus carica L. cv. Brown Turky). Pak. J. Bot. 50(5):1753-1758. 